\title{
Influence of austempering temperature and salt bath agitation on microstructure and mechanical properties of austempered ductile iron
}

\author{
N. Čatipović*, D. Živković, Z. Dadić, J. Krolo \\ Faculty of Electrical Engineering, Mechanical Engineering and Naval Architecture, University of Split, \\ Rudera Boškovića 32, 21000 Split, Republic of Croatia
}

Received 24 January 2018, received in revised form 15 May 2018, accepted 21 May 2018

\begin{abstract}
The influence of austempering temperature and salt bath agitation on microstructure and mechanical properties of austempered ductile iron was studied. The as-cast specimens of ductile iron were subjected to heat treatments consisting of austenitisation at $900^{\circ} \mathrm{C}$ for $1 \mathrm{~h}$ followed by austempering at temperatures ranging from 230 to $450^{\circ} \mathrm{C}$ in a salt bath with and without agitation. The volume fraction of retained austenite increases with increasing austempering temperature to about $395^{\circ} \mathrm{C}$ and decreases at higher austempering temperatures. The austempering at lower temperatures leads to the formation of finer microstructures. The agitation of the salt bath leads to the formation of the higher volume fraction of ausferrite at the expense of the retained austenite compared to that of the specimens prepared without salt bath agitation. Vickers hardness decreases with increasing austempering temperature and increasing volume fraction of the retained austenite. Room temperature impact energy increases with increasing austempering temperature to about $395^{\circ} \mathrm{C}$ and then decreases at higher temperatures. The impact energy increases with increasing volume fraction of the retained austenite. The proposed mathematical models are of industrial importance for prediction of Vickers hardness, impact energy and volume fraction of the retained austenite as functions of austempering temperature and agitation or no agitation of the salt bath.
\end{abstract}

Key words: austempered ductile iron, heat treatment, microstructure, mechanical properties

\section{Introduction}

Over the last years, the market has been facing huge demand for tough, durable and economically viable materials. Ductile cast iron represents one of such interesting materials for applications in different sectors including military, construction, earthmoving, trucks, automotive, railway and agricultural [1]. For example, some of the most used automotive components are gears, crankshafts, connecting rods, camshafts, timing gear supports, engine mounts, transmissions, suspension components and tow hooks. Isothermal heat treatments of ductile cast iron lead to the formation of completely new phase in austempered ductile iron (ADI) known as ausferrite. The ADI has a unique microstructure and significantly better mechanical properties (hardness, toughness, and strength) than those of as-cast ductile iron [24]. The microstructure of ADI is a mixture of fine acicular ferrite and stable, high carbon enriched retained austenite called ausferrite [3, 4]. Compared with pearlitic, ferritic or martensitic microstructures, the tensile strength of the ausferrite is nearly doubled at a given ductility level [4-10]. Austempered matrix provides better tensile strength and ductility ratio than any other types of ductile cast irons. Various

\footnotetext{
*Corresponding author: e-mail address: Niksa.Catipovic@fesb.hr
} 
Table 1. Chemical composition of ductile iron (wt.\%)

\begin{tabular}{lccccccc}
\hline Label & $\mathrm{C}$ & $\mathrm{Si}$ & $\mathrm{Mn}$ & $\mathrm{P}$ & $\mathrm{S}$ & $\mathrm{Cu}$ & $\mathrm{Mg}$ \\
\hline NK40-KF & 3.63 & 2.52 & 0.20 & 0.04 & 0.008 & 0.04 & 0.047 \\
\hline
\end{tabular}

combinations of mechanical properties resulting from ausferritic microstructure of ADI can be obtained by a combination of heat treatment parameters and alloying elements [11].

Heat treatments of ADI consist of austenitisation of ductile iron, quenching in an austempering medium, holding on austempering temperature and cooling to room temperature [12-18]. Several authors [3, 4, 19] have reported that ADI undergoes phase transformation processes consisting of two stages. During the first stage, austenite $(\gamma)$ decomposes into bainitic ferrite $(\alpha)$ and carbon-enriched retained austenite $\left(\gamma_{\mathrm{hc}}\right)$. During the second stage, the carbon-enriched retained austenite further decomposes into ferrite $(\alpha)$ and carbides. This decomposition occurs if the ductile iron is held for a too long time at austempering temperature [3]. Optimal mechanical properties of ADI are achieved upon the completion of the first stage of transformation because the occurrence of carbides in the microstructure makes the material brittle [20, 21].

The austempering transformation can be done in lead bath, but its melting point of $327^{\circ} \mathrm{C}$ narrows temperature range of austempering heat treatment. Exceptionally, oil bath can also be used but with high caution [22]. Salt baths are the most often used for austempering heat treatment. They are also used for tempering, annealing, austenitisation, quenching, etc. The most commonly used salt baths are composed of $\mathrm{NaNO}_{3}$ and $\mathrm{KNO}_{3}$. Operating temperature range of these salt baths is between 160 and $550{ }^{\circ} \mathrm{C}$ and depends on the chemical composition of heat-treated materials. Molten salts are completely dissolved in cations and anions, which are thermally very stable. Some molten salts can even dissolve metals [23, 24].

This paper aims to study the influence of austempering temperature and salt bath agitation on microstructure and mechanical properties of austempered ductile cast iron. Planning of experiments concerning input parameters is carried out. Austempering temperatures and agitation or no agitation of the salt bath are used as the input parameters for calculation of an optimal number of experiments.

\section{Experimental procedure}

Figure 1 shows as-received ductile iron with a chemical composition given in Table 1 . The ductile iron was prepared by sand casting in the form of Y-block, as shown in Fig. 1a. For this study,
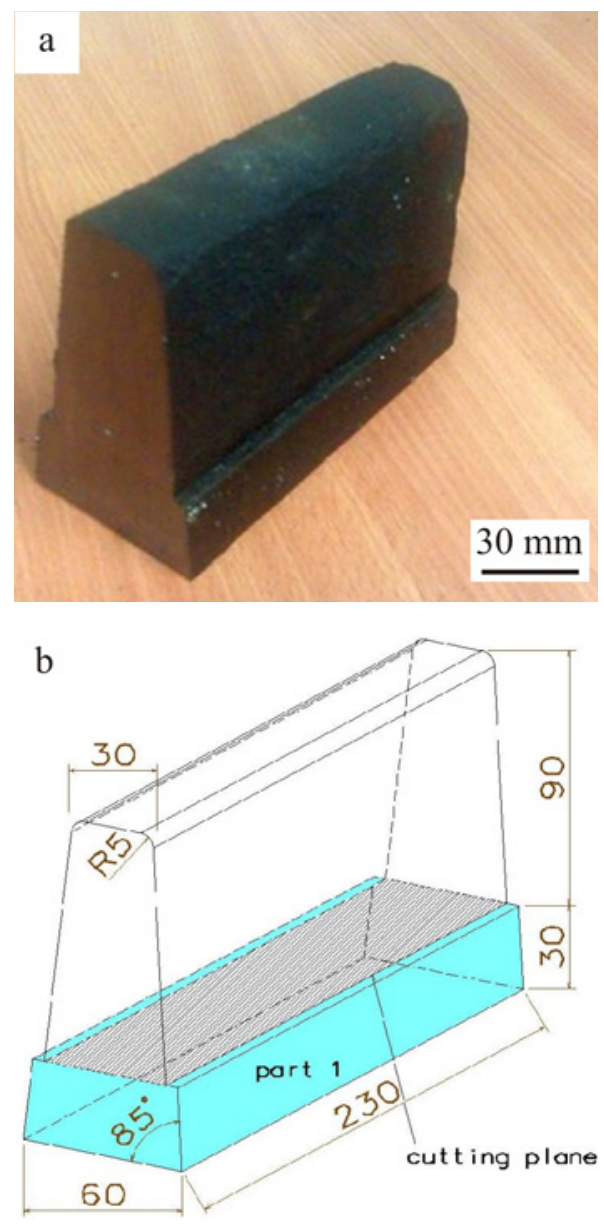

Fig. 1. As-cast Y-block of ductile iron (a) and schematic representation of Y-block dimensions (b).

only bottom part of the block with dimensions of $50 \times 230 \times 30 \mathrm{~mm}^{3}$ (part I) was cut from the asreceived block, as seen in Fig. 1b. The bottom part of the block was cut into smaller pieces which were used for machining of Charpy V-notch specimens with dimensions shown in Fig. 2. The Charpy specimens were subjected to heat treatments consisting of austenitisation and austempering. The austenitisation was carried out at a temperature of $900^{\circ} \mathrm{C}$ for $1 \mathrm{~h}$. After the austenitisation stage, the specimens were directly transferred into a salt bath consisting of $50 \%$ $\mathrm{NaNO}_{3}$ and $50 \% \mathrm{KNO}_{3}$ and austempered at temperatures ranging from 230 to $450^{\circ} \mathrm{C}$ for $1 \mathrm{~h}$. The heat treatments were finalised by air cooling of the specimens to room temperature. 
Table 2. Experiment plan

\begin{tabular}{cccc}
\hline Sample label & Experimental number & Austempering temperature $\left({ }^{\circ} \mathrm{C}\right)$ & Salt bath agitation \\
\hline 13 & 1 & 230 & With \\
3 & 2 & 230 & With \\
11 & 3 & 395 & Without \\
17 & 4 & 307 & With Without \\
12 & 5 & 258 & With \\
1 & 6 & 394 & Without \\
15 & 7 & 230 & Without \\
14 & 8 & 450 & Without \\
4 & 9 & 450 & With \\
5 & 10 & 230 & Without \\
8 & 11 & 450 & With \\
7 & 12 & 307 & With \\
10 & 13 & 352 & Without \\
\end{tabular}

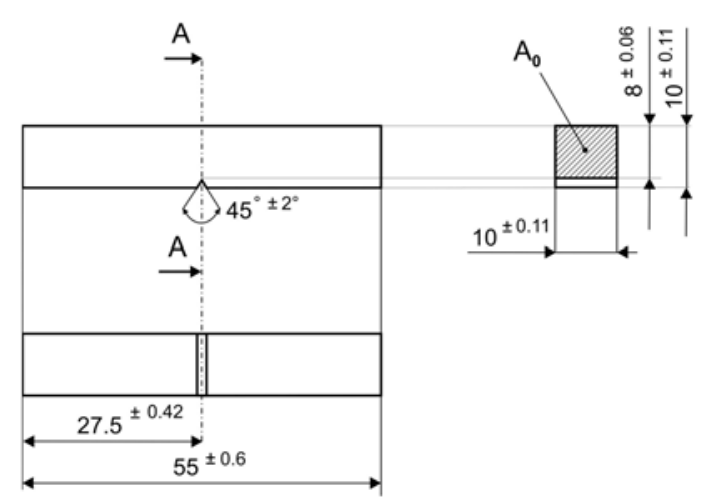

Fig. 2. Standardised Charpy V-notch specimen dimensions.

Planning of experiments concerning input parameters was performed by Design Expert software. The cubic model was selected for Response Surface Method (RSM) study type with D-optimal initial design. The austempering temperatures ranging from 230 to $450^{\circ} \mathrm{C}$ and agitation or no agitation of the salt bath were used as the input parameters for calculation of an optimal number of experiments. The applied cubic model resulted in 17 experiments which data are necessary to reliably predict mechanical properties in relation to input parameters, as seen in Table 2.

The specimens for microstructural analysis were ground on abrasive papers of different grain sizes and mechanically polished on aluminium oxide suspension. The final step of the metallographic preparation included etching with Nital (a mixture of alcohol and $3 \%$ nitric acid). The microstructure observations were carried by a light microscope. Volume fractions of phases in as-cast and heat-treated specimens were measured by image analysis software ImageJ.

Vickers hardness HV10 was measured at an applied load of $98 \mathrm{~N}$ using universal hardness machine according to ISO standard 6507-1:2005. Average hardness values were calculated from five different measurements.

Fracture impact energy was measured using heattreated V-notch specimens and standardised Charpy pendulum with an impact energy of $300 \mathrm{~J}$. Measurements were carried out at room temperature according to ISO standard 148-1:2009.

\section{Results and discussion}

\subsection{As-cast microstructure}

Figure 3 shows the typical as-cast microstructure of the ductile iron specimens before heat treatments. The as-cast microstructure consists of 52 vol.\% of ductile ferrite $(\alpha), 21$ vol.\% of graphite nodules $(\mathrm{g})$, and 27 vol.\% of pearlite $(\mathrm{P})$.

The ductile iron is not a single material but part of a group of materials which can be produced with a wide range of properties through control of their microstructure resulting from stable and metastable phase transformations. During cooling cementite forms first until all magnesium in the ductile iron is consumed. Under the influence of silicon, cementite decomposes, and carbon forms graphite nodules which are responsible for the quality of ductile iron. Nodularity of ductile iron is defined by a proportion of volume fraction of spherical graphite particles to the total volume fraction of graphite. The production aims to obtain ductile iron with as much nodularity as possible, usually above $90 \%[25,26]$. The high 




Fig. 3. The as-cast microstructure of ductile iron specimens.

silicon content of the ductile iron suppresses the formation of carbides normally associated with bainitic reactions, allowing carbon rejected by the formation of ferrite to enrich the carbon content of the retained austenite.
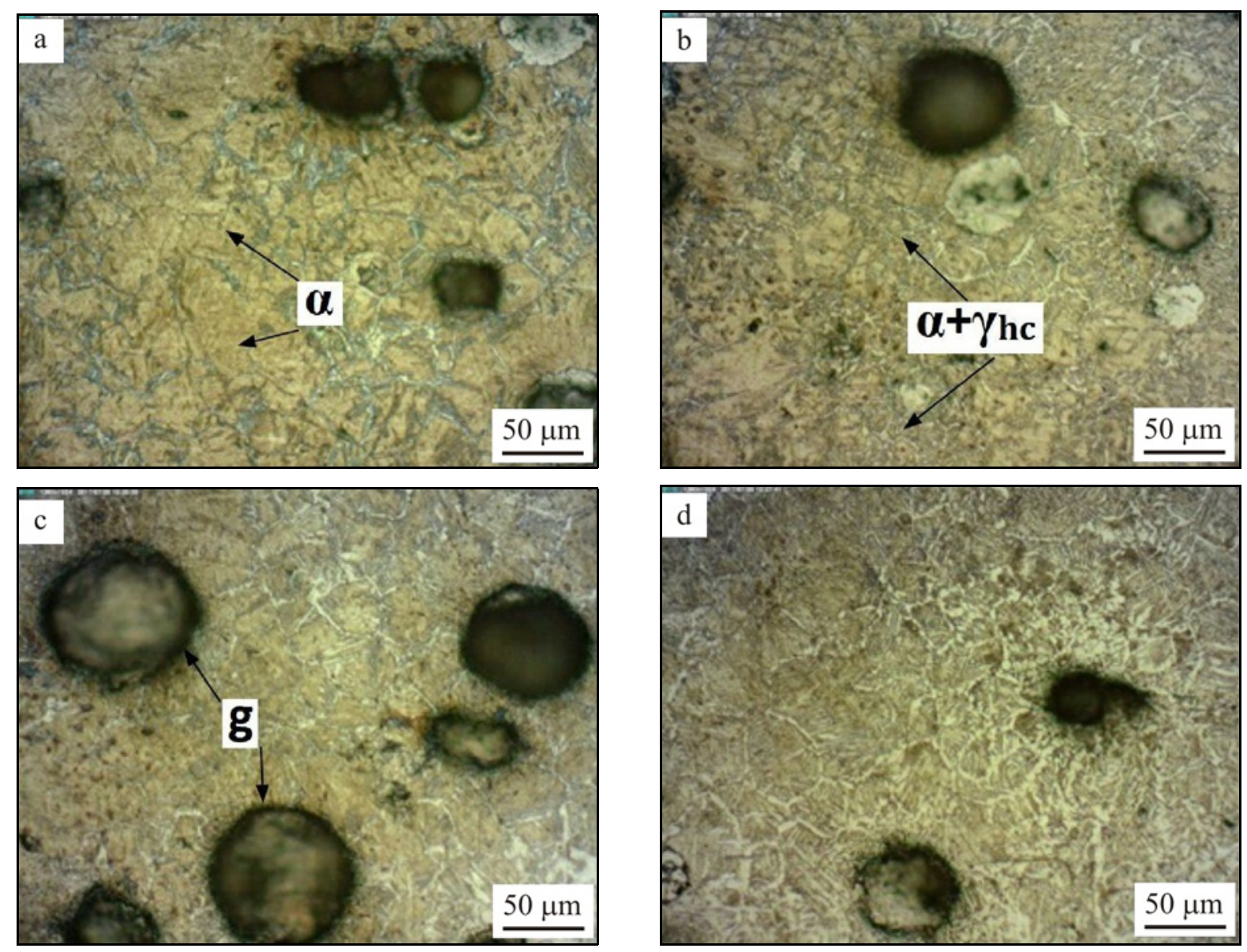

Fig. 4. ADI microstructures after austempering with salt bath agitation at temperatures of (a) $230^{\circ} \mathrm{C}$, (b) $307^{\circ} \mathrm{C},(\mathrm{c})$
Mechanical properties of ductile iron such as fatigue strength and ultimate tensile strength severely decrease with increasing amount of non-nodular graphite particles while nodularity has only a small effect on yield strength. Thin graphite leaves with sharp edges lead to a decrease of ultimate tensile strength. Lower nodularity decreases elastic modulus, fracture impact energy, electric resistance and increases vibration damping and heat conductivity of ductile iron $[26]$.

\subsection{Effect of heat treatments on microstructure}

Figure 4 shows microstructures of ductile iron specimens after austempering with the salt bath agitation. Figure 5 shows microstructures after austempering at different temperatures without the salt bath agitation. From Figs. 4 and 5, it is clear that the typical ausferrite microstructure is formed. The microstructure consists of graphite nodules $(\mathrm{g})$ and a mixture of ausferrite $\left(\alpha+\gamma_{\mathrm{hc}}\right)$ and ferrite $(\alpha)$. The ausferrite is formed from the austenite enriched with carbon.

$$
352^{\circ} \mathrm{C} \text {, and (d) } 423^{\circ} \mathrm{C} \text {. }
$$



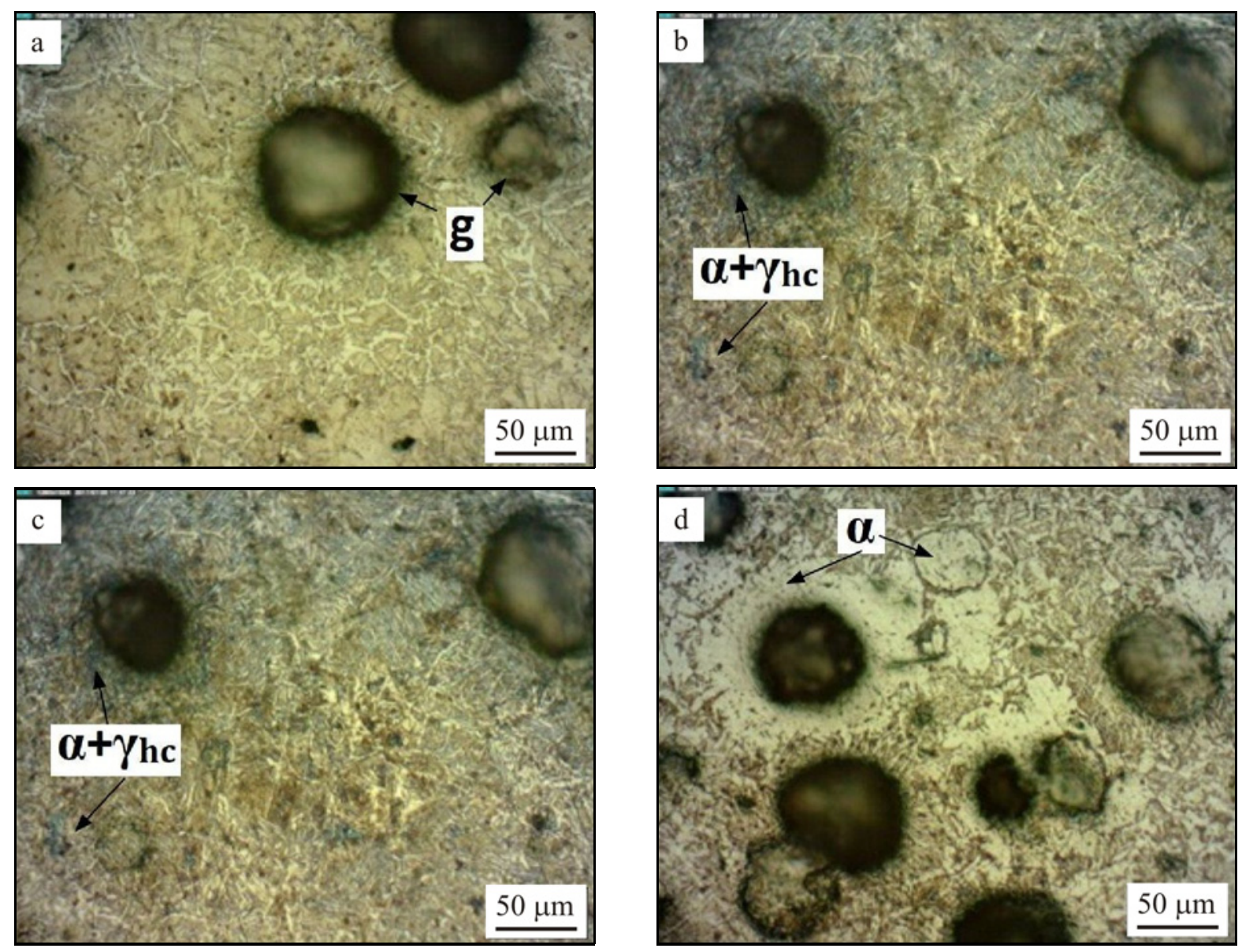

Fig. 5. ADI microstructures after austempering without salt bath agitation at temperatures of (a) $258^{\circ} \mathrm{C}$, (b) $368^{\circ} \mathrm{C},(\mathrm{c})$ $395^{\circ} \mathrm{C}$, and (d) $450^{\circ} \mathrm{C}$.

During the austenitisation process, the enrichment of the austenite by carbon is achieved by the diffusion of carbon from ferrite or carbides. In ferritic ductile irons, there is only a small amount of carbon in ferrite so austenite cannot be enriched enough to form ausferrite during austempering heat treatments. Ductile irons with pearlitic microstructure can be subjected to austempering because pearlite contains eutectoid cementite from which carbon can diffuse into austenite during austenitisation and create ausferrite during consecutive austempering. It should be noted that the graphite nodules are thermodynamically stable in the microstructure of the ductile iron up to about $1500^{\circ} \mathrm{C}$ and cannot contribute to the enrichment of austenite by carbon during austenitisation.

Figure 6 shows the dependence of volume fraction of retained austenite on austempering temperature. The volume fraction of the retained austenite increases with increasing austempering temperature to about $395^{\circ} \mathrm{C}$ and then decreases at higher temperatures. The agitation of the salt bath leads to a decrease of the volume fraction of the retained austenite. The low volume fraction of the retained austenite at lower temperatures is connected with lower carbon diffusion rate

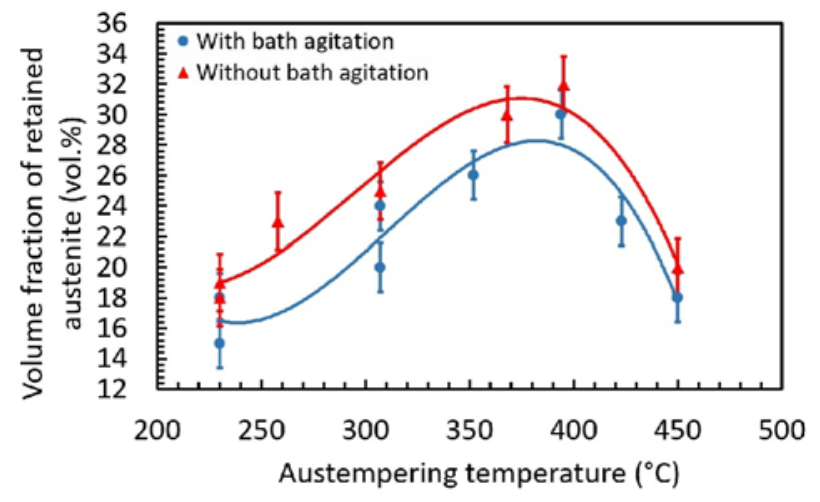

Fig. 6. Dependence of volume fraction of retained austenite on austempering temperature. The austempering with and without salt bath agitation is indicated in the figure.

which leads to an increase of ferrite formation. The excess of carbon trapped inside ferrite promotes precipitation of different carbides, mainly silicon carbides which form at the same time as ausferrite [1]. Consequently, the volume fraction of the retained austenite decreases by decomposition to ferrite and carbides at 


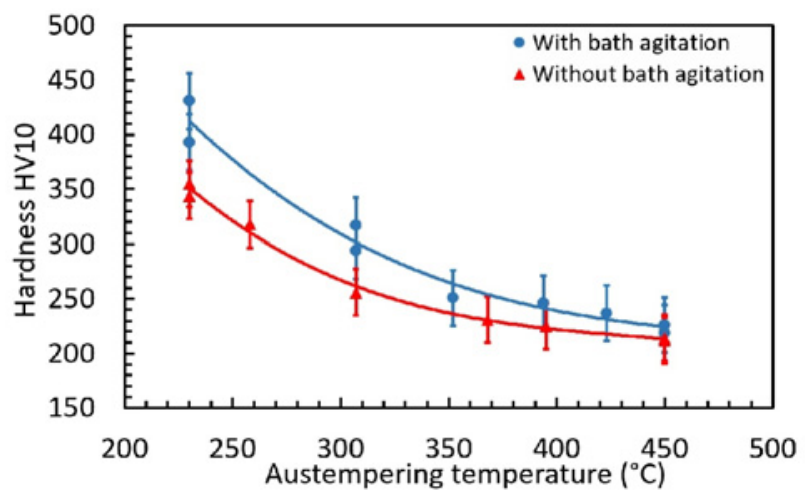

Fig. 7. Dependence of Vickers hardness HV10 on austempering temperature. The austempering with and without salt bath agitation is indicated in the figure.

higher temperatures or when the austempering times are longer [26]. The RSM analysis of experimentally measured volume fraction of the retained austenite $V_{\gamma_{\mathrm{hc}}}$ for the specimens austempered with the salt bath agitation yields an equation in the form:

$$
V_{\gamma_{\mathrm{hc}}}=31.258-0.122 T_{\mathrm{a}}+2.253 \times 10^{-4} T_{\mathrm{a}}^{2},
$$

where $T_{\mathrm{a}}$ is the austempering temperature. The correlation coefficient of this fit is $r^{2}=0.886$. The volume fraction $V_{\gamma_{\mathrm{hc}}}$ for the specimens prepared without the salt bath agitation can be expressed in the form:

$$
V_{\gamma_{\mathrm{hc}}}=32.477-0.188 T_{\mathrm{a}}+2.532 \times 10^{-4} T_{\mathrm{a}}^{2} .
$$

The correlation coefficient of this fit is $r^{2}=0.9445$.

\subsection{Effect of heat treatments on mechanical properties}

The measured mechanical properties are analysed statistically. The statistical analysis is carried out by ANOVA which is the part of Design Expert software. Figure 7 shows that the Vickers hardness HV10 decreases with increasing austempering temperature for both types of specimens prepared with and without agitation of the salt bath. It is clear that the agitation of the salt bath leads to significantly higher hardness values compared to those of the specimens prepared without agitation. The agitation of the salt bath leads to an improved heat dissipation which is connected with an increase of cooling rate during the austempering [27]. Higher hardness values measured at lower austempering temperatures can be related to low carbon diffusion rate which promotes the formation of a higher amount of ferrite [28]. The precipitation of different types of carbides such as silicon carbides can be identified in the studied alloy during the decomposition of the austenite at lower temperatures. Us-

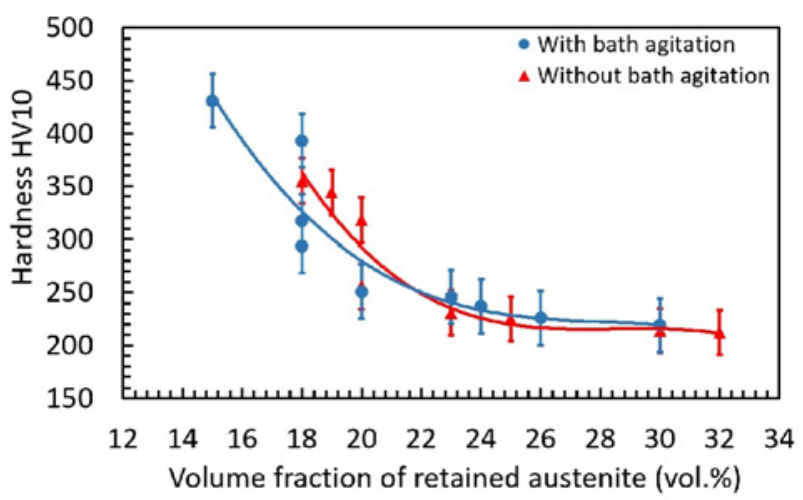

Fig. 8. Dependence of Vickers hardness HV10 on the volume fraction of retained austenite. The austempering with and without salt bath agitation is indicated in the figure.

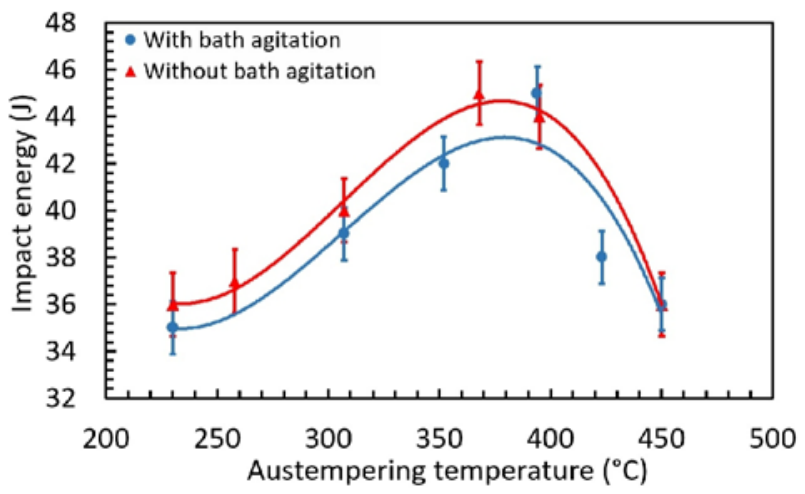

Fig. 9. Dependence of impact energy on austempering temperature. The austempering with and without salt bath agitation is indicated in the figure.

ing RSM analysis, the Vickers hardness HV10 for the specimens prepared with the salt bath agitation can be described in the form:

$$
\mathrm{HV} 10=975.482-3.283 T_{\mathrm{a}}+3.589 \times 10^{-3} T_{\mathrm{a}}^{2} .
$$

The correlation coefficient of this fit is $r^{2}=0.9936$.

For the specimens prepared without the salt bath agitation, the RSM analysis results in the equation in the form:

$$
\mathrm{HV} 10=862.245-3.05 T_{\mathrm{a}}+3.589 \times 10^{-3} T_{\mathrm{a}}^{2} .
$$

The correlation coefficient of this fit is $r^{2}=0.9728$. The measured hardness values can also be related to the volume fraction of the retained austenite, as seen in Fig. 8. The hardness decreases continuously with increasing volume fraction of the retained austenite.

Figure 9 shows the dependence of measured impact energy on austempering temperature. The impact energy follows qualitatively evolution of the volume frac- 




Fig. 10. Dependence of impact energy on the volume fraction of retained austenite. The austempering with and without salt bath agitation is indicated in the figure.

tion of the retained austenite with the austempering temperature. The impact energy increases with increasing austempering temperature to about $395^{\circ} \mathrm{C}$ and then decreases at higher temperatures. For the specimens prepared with the salt bath agitation, the RSM analysis of experimentally measured values of impact energy KV leads to an equation in the form:

$$
\begin{gathered}
\mathrm{KV}=174.104-1.487 T_{\mathrm{a}}+5.107 \times 10^{-3} T_{\mathrm{a}}^{2} \\
-5.527 \times 10^{-6} T_{\mathrm{a}}^{3} .
\end{gathered}
$$

The correlation coefficient of this fit is $r^{2}=0.8761$. Using the RSM analysis, the KV for the specimens prepared without the salt bath agitation can be described in the form:

$$
\begin{gathered}
\mathrm{KV}=169.199-1.447 T_{\mathrm{a}}+5.045 \times 10^{-3} T_{\mathrm{a}}^{2} \\
-5.527 \times 10^{-6} T_{\mathrm{a}}^{3} .
\end{gathered}
$$

The correlation coefficient of this fit is $r^{2}=0.9942$.

The high impact energy values measured at temperatures about $395^{\circ} \mathrm{C}$ can be explained by an optimal amount of ausferrite in the microstructure of the austempered specimens. At the austempering temperatures higher than about $395^{\circ} \mathrm{C}$, the volume fraction of the retained austenite decreases because ausferrite decomposes into ferrite and carbides during the second stage of the phase transformation. This undesirable transformation leads to deterioration of the mechanical properties, both hardness and impact energy, as seen in Figs. 7 and 9. Similar results have also been reported by Eric et al. [29] for $\mathrm{Cu}-\mathrm{Ni}-\mathrm{Mo}$ austempered ductile iron.

Figure 10 shows the dependence of impact energy on the volume fraction of retained austenite. For both types of specimens prepared with and without salt bath agitation, the impact energy increases with increasing volume fraction of the retained austenite. As shown by Lapin et al. [30, 31], impact energy can be qualitatively related to dynamic and static fracture toughness measured by Charpy and three-point bending tests, respectively, using $\mathrm{V}$-notch specimens. Hence, it is expected that not only the impact energy but also fracture toughness of the studied austempered ductile iron increases with increasing volume fraction of the retained austenite.

\section{Conclusions}

The influence of austempering temperature and salt bath agitation on microstructure and mechanical properties of austempered ductile iron was studied. The achieved results can be summarised as follows:

1. The microstructure of as-cast ductile iron consists of a ductile ferritic matrix with graphite nodules and a small amount of pearlite. The volume fractions of coexisting phases are measured to be: 52 vol. $\%$ of ferrite, 21 vol. $\%$ of graphite nodules, and 27 vol. $\%$ of pearlite.

2. The volume fraction of the retained austenite increases with increasing austempering temperature to about $395^{\circ} \mathrm{C}$ and decreases at higher austempering temperatures. The austempering at lower temperatures leads to the formation of finer microstructure with the lower volume fraction of the retained austenite $\left(V \gamma_{\mathrm{hc}}=15-19\right.$ vol.\% $)$ than that of the specimens heat-treated at higher austempering temperatures $\left(V \gamma_{\mathrm{hc}}=30-32 \mathrm{vol} . \%\right)$.

3. The agitation of the salt bath leads to the formation of the higher volume fraction of ausferrite at the expense of the retained austenite compared to that of the specimens prepared without the salt bath agitation. The austempering without the salt bath agitation preserves higher volume fraction of the retained austenite in the microstructure of ADI specimens.

4. Vickers hardness decreases with increasing austempering temperature and increasing volume fraction of the retained austenite. Room temperature impact energy increases with increasing austempering temperature to about $395^{\circ} \mathrm{C}$ and then decreases at higher temperatures. The impact energy increases with increasing volume fraction of the retained austenite.

5. The proposed mathematical models are of industrial importance for prediction of Vickers hardness, impact energy and volume fraction of the retained austenite as functions of austempering temperature and agitation or no agitation of the salt bath.

\section{Acknowledgements}

This work has been fully supported by the Croatian Science Foundation under the project 5371. 


\section{References}

[1] Harding, R. A.: Kovove Mater., 45, 2007, p. 1.

[2] Behera, G., Sohala, S. R.: Effect of Copper on the Properties of Austempered Ductile Iron Castings. [Bachelor Thesis]. Rourkela, Department of Metallurgical and Materials Engineering, National Institute of Technology 2012.

[3] Sidjanin, L., Smallman, R. E.: Mater. Sci. Tech., 8, 1992, p. 1095. doi:10.1179/mst.1992.8.12.1095

[4] Stamborská, M., Lapin, J., Bajana, O., Losertová, M.: Kovove Mater., 53, 2015, p. 399. doi:10.4149/km_2015_6_399

[5] Stamborská, M., Lapin, J., Bajana, O.: Kovove Mater., 54, 2016, p. 397. doi:10.4149/km_2016_6_397

[6] Saatci, T., Salamci, E.: Kovove Mater., 55, 2017, p. 333. doi:10.4149/km_2017_5_333

[7] Karimi, A., Kheirandish, S., Mahmoudiniya, M.: Kovove Mater., 55, 2017, p. 175. doi:10.4149/km_2017_3_175

[8] Panneerselvam, S., Putatunda, S. K., Gundlach, R., Boileau, J.: Mat. Sci. \& Eng. A, 694, 2017, p. 72. doi:10.1016/i.msea.2017.03.096

[9] Wang, B., Barber, G. C., Tao, C., Sun, X., Ran, X.: J Mater Res Technol., 7, 2017, p. 198. doi:10.1016/j.jmrt.2017.08.011

[10] Elliot, R.: Heat Treatments of Metals, 23, 1997, p. 55.

[11] Chandler, H.: Heat Treater's Guide: Practices and Procedures for Irons and Steels. 2nd Edition. Materials Park, ASTM International 1995.

[12] Sharma, A., Singh, K. K., Gupta, G. K.: In: Proceedings of the $6^{\text {th }}$ International \& $27^{\text {th }}$ All India Manufacturing Technology, Design and Research Conference (AIMTDR-2016). College of Engineering, Pune 2016, p. 1056. ISBN: $978-93-86256-27-0$

[13] Živković, D., Gabrić, I., Dadić, Z., Catipović, N., Vrljičak, I.: In: Proceedings of MTSM 2015, Croatian Society for Mechanical Engineering Technology, Split 2015. ISSN 1847-7917 (in Croatian).

[14] Čatipović, N., Živković, D., Dadić, Z., Sučić, A., Ljumović, P.: In: Proceedings of MTSM 2015, Croatian Society for Mechanical Engineering Technology, Split 2015. ISSN 1847-7917 (in Croatian).
[15] Eric, O., Rajnovic, D., Zec, S., Sidjanin, L., Jovanovic, M. T.: Mater. Charact., 57, 2006, p. 211. doi:10.1016/j.matchar.2006.01.014

[16] Kovac, B. V.: Mod. Cast., 80, 1990, p. 38.

[17] Sidjain, L., Rajnovic, D., Eric. O., Smallman, R. E.: Mat. Sci. and Tech., 26, 2010, p. 567. doi:10.1179/174328409X407524

[18] Sidjanin, L., Smallman, R. E., Young, J. M.: Acta Mater., 42, 1994, p. 3149. doi:10.1016/0956-7151(94)90412-X

[19] Rajnovic, D., Eric, O., Sidjanin, L.: Kovove Mater., 50, 2012, p. 199. doi:10.4149/km_2012_3_199

[20] Gagné, M.: The Sorelmetal Book of Ductile Iron. Montreal, Rio Tinto Iron \& Titanium 2004.

[21] ASM Metals Handbook Volume 04 - Heat Treatment, Heat Treating of Ductile Irons. 1498. Materials Park, ASM International 2014.

[22] Dubal, G. P.: Advanced Materials \& Processes, 156, 1999, p. H23.

[23] Hef Durferrit. http://www.hefdurferrit.de/en/

[24] Žmak, I.: Modeling the Structure and Properties of Ductile Iron Using Neural Networks. [Doctoral Thesis]. Zagreb, FSB 2008.

[25] Metals Handbook. Casting. Volume 15. 9th Edition. Metals Park, ASM International 1988.

[26] Yescas, M. A., Bhadeshia, H. K. D. H., MacKay, D. J.: Mat. Sci. and Eng. A, 311, 2001, p. 162. doi:10.1016/S0921-5093(01)00913-3

[27] Harding, R. A.: Austempered Ductile Iron Components - Advantages, Production, Properties and Specifications. Birmingham, BCIRA 1991.

[28] Harding, R. A.: In: Proceedings of BCIRA Int. Conf. Castings to Satisfy our Customers. Birmingham, BCIRA 1989, Paper 18.

[29] Eric, O., Sidjanin, L., Miskovic, Z., Zec, S., Jovanovic, M. T.: Mater. Lett., 58, 2004, p. 2707. doi:10.1016/j.matlet.2004.02.041

[30] Lapin, J., Klimová, A., Gabalcová, Z., Pelachová, T., Bajana, O., Štamborská, M.: Mater. Des., 133, 2017, p. 404. doi:10.1016/j.matdes.2017.08.012.

[31] Lapin, J., Stamborská, M., Pelachová, T., Bajana, O.: Mater. Sci. Eng. A., 721, 2018, p. 1. doi:10.1016/j.msea.2018.02.077 